AFTER THE END 



\section{AFTER THE END}

Making U.S. Foreign Policy in the Post-Cold War World

Edited by James M. Scott

Duke University Press Durham and London 1998 
(C) I998 Duke University Press

All rights reserved

Printed in the United States of America on acid-free paper $\circledast$

Typeset in Trump Mediaeval by Tseng Information Systems, Inc.

Library of Congress Cataloging-in-Publication Data appear

on the last printed page of this book.

Second printing, 2000 
For Meghan Rose and Michael James 
